\title{
Media Literacy: The Real, Interactive Way and Being Ethical Within Post Conflict Non-Catharsis Society in Bosnia and Herzegovina
}

\section{Sabahudin Hadžialić ${ }^{14}$}

\begin{abstract}
Who is responsible for the media's current state of affairs? Is there any greater freedom of expression today, or is it a greater repression, or is it two sides of the same coin? The so-called "libertarian society" has come to the place of the desired "healthy society", and thus we appear to have moral anarchy. Above all, the interests of big capital and politics, technological unpreparedness, and non-compliance with ethical and professional standards prevail and overcome all.
\end{abstract}

There is also the problem of over-production of too many young people in the media field who possess poor skills, the result of the lack of a good education and monitoring of contemporary trends in journalism, as well as too many media outlets for such a small space such as Bosnia and Herzegovina (everything written about this country relates as well to Serbia, Montenegro, Croatia, Macedonia and Kosovo*). It is not questionable that there is freedom of speech, but its application is mostly abusive or inadequate.

Media owners, journalists and editors are not difficult to pay for slander punishment and similarly when they have met the goal - to smear someone, spin real problems, etc. - BiH's libertarian society (if we can call it that) should be seen in the context of a non-free, captive and imprisoned society, a society that is chained to poverty, existential fear, subject to an epidemic of ignorance coupled with the absence of elemental courage and curiosity.

Keywords: Media Literacy, Education, Journalism, Media Ethics, Media Laws, Catharsis, Bosnia and Herzegovina

14 Assoc. Prof. Dr. \& Dr., Communication science faculty, UNINETTUNO University, Rome, Italy, sabahudin.hadzialic@uninettunouniversity.net. ORCID: https://orcid.org/0000-0002-7607-2436. 


\section{INTRODUCTION}

\section{FREEDOM of SPEECH and POVERTY}

Freedom of journalistic speech and expression in such a society is primarily limited by the employers' interests and the fact that journalism, as it is currently being sought in the labor market, appears to argue that anybody can be a journalist. This is happening, while the authors of the commentaries and important columns within the newspapers with the highest circulation, as the most respected form of writing in journalism, are often under the legal age, and lack experience, both professional and in real life. This is unacceptable from the perspective of professional ethical standards, if such a thing does indeed exist.

Often, in the newsrooms, the sentence is heard: "Whoever does not like it, then he/she can go, as I can find a new person for 100 euros per month on the street." And what is even worse, that's the truth. People under the pressure of poverty and unemployment are willing to work, not only for 100 euros, but for free, just to get involved in the profession, and there is no positive selection of staff as more microphone holders are required, than quality and engaging journalists.

With their willingness to look under each stone, such journalists often even annoy employers as boring and even dangerous people who can make problems with advertisers, patrons, political and business friends. Here's a banal example of what I am writing about: when is the last time that you have seen an article or commentary that examines the work of a Telecom operator?

The media are almost totally subordinated to political elites and national interests, which is why they have lost their freedom. Let's take examples in the Federation of Bosnia and Herzegovina (entity of $\mathrm{BiH}$ ) where we can immediately talk about who is currently in power (the left and / or right option within one nation) by the chosen topics of public service TV - while in the Republika Srpska (entity in $\mathrm{BiH}$ ) we have two equally powerful TV companies one public TV service - RTRS, and the other private TV channel - BN TV belonging to different political options. Has 
there ever happened a case that an option that is under the "control" of any one of the media mentioned above is this media "asking" that "option" for this or that? Unfortunately, not. And that is why professional ethical standards of journalism are in question. "Where everyone thinks the same, no one thinks the God knows what", said the great Duško Radovic (former Yugoslav writer and journalist, Belgrade 1922-1984) in the eighties of the last century.

It is believed that the above-mentioned penury has contributed to the reduction of media freedom. As an example, we can state that in the years after the war (1992-1995) in Bosnia and Herzegovina international donors donated millions of euros, and because of that it was easier for journalists to write and speak, as they were not dependent on anyone in the country.

The beginning of the 21 st Century brought a rapid reduction in these donations. In fact, today it is possible to speak about very small amounts in relation to those immediately after the war. Because of this, the media have been subjected, when seeking funding sources, to look to the other side. Given that $\mathrm{BiH}$ is more and more dependent on political interests, as a result of the public and private sector of the economy largely financing the media, so the media have become politically dependent. The very fact that the strongest tycoons are, depending on the economic and territorial area they cover, in direct connection with political actors, has led to the interaction of the organized alignment of indirect pressures on the media that leads to blackout or underestimation, since the circulation of "inappropriate media to a reasonable measure" cannot harm "wider" interests.

\section{MONEY MAKES JOURNALISTS GO AROUND}

Since the money is mostly in the hands of parties and companies associated with them, it is very difficult for the media to survive if they do not have someone behind them. Much of the media, especially in the Republika Srpska (BiH entity), are funded from the state budget. Can they criticize the government that finances them? A lot of issues are addressed by professional ethical standards in these areas, which are under the umbrella of precisely designating subjects of political pluralism in the context of the development of a healthy society. 
A recently released World Press Freedom Index claims that $\mathrm{BiH}$ is in the 58th place, and after which many media said that media freedom in $\mathrm{BiH}$ has stagnated. Namely, in $2006 \mathrm{BiH}$ was ranked 19th, and in 2010 at 47th. Place out of 180 countries included within the ranking..quote from WPFI: "The polarised political climate, marked by constant verbal attacks and nationalist rhetoric, has created a hostile environment for press freedom. Editorial policies reflecting ethnic divisions and hate speech are ever more evident. Journalists are attacked for their ethnic origins as well as what they write. Defamation suits by politicians often serve to intimidate journalists and deter them from pursuing their work."..end of quote.

I am convinced that instead of "stagnation", it would have been better to say that the situation in the media has changed and that the pressures have now been embedded into the system, and by that they are less visible, recognizable and far worse, in the long run. While the situation is no better in other countries in the region, in $\mathrm{BiH}$ this influence is more pronounced because of the economic and social situation, including a deep national division between ethnic groups: Bosniaks, Croats and Serbs.

Specifically, try to be a Journalist journalist of daily "Dnevni avaz" and publish something against Fahrudin Radončić or a journalist of daily "Nezavisne novine" and criticize Milorad Dodik, or even a journalist of the daily "Oslobođenje" and write something against the owner of Oslobođenje, Mujo Selimović. It's simply impossible. First of all because of self-censorship, because journalists are aware that something like this would not past the editor's desk and as such they don't even try, but even if they did try, such a text would not be published - and we aren't even to speaking about the consequences for the journalist.

And there are still a number of such examples. On the one hand, this can be understood in the context of the fear of journalists and that more and more of them are left out of jobs. But for the profession - professional journalism — it's a disaster! Those who are willing to sell their human and 
professional dignity to (even a small one) salary, a free ride with or smile of a politician should not be doing this job. By doing such, they are doing a disservice not only to him/her, but also to the ethics of journalism.

There are legal frameworks in $\mathrm{BiH}$ that provide an undisturbed working atmosphere for journalists, and that is largely a good basis for respect for media freedom, but these do not apply in practice.

However, in addition to legal regulations, physical attacks on journalists' teams, court bans, police clashes in the newsroom, denial of accreditation for certain journalists and verbal attacks, are just a part of what journalists in $\mathrm{BiH}$ are suffering. Since 2006, 65 physical assaults on journalists and direct threats to death have been reported, and only $15 \%$ of criminal offenses against journalists have been faced with final judgments.

It is true that Bosnia and Herzegovina has a pretty good legislation that would be envied by journalists who are fighting against the hardcore restrictions and free information in many countries around the world. It is far away, however, though, to say that in $\mathrm{BiH}$ we are satisfied. The growing political pressures on the media, the information (half-information and fake news) that journalists receive, pressures from media owners towards journalists, have influenced that all of these laws are almost not being applied. Why this exists? Simply, because of lack of media literacy education, development of critical thinking and "blame on other side" always for any mistake within your own ethnic group. War ended in 1995, but as the time is passing by it looks like it stopped yesterday and will continue tomorrow. Again, why? Because, it is much easier to educate" a public to hate other and different ones instead of developing education which will develop critical thinking of own problems which, eo ipso, will help to overcome exactly this problems. But, politicians from all three involved mentioned sides know (and support each other so well in that) how to ,teach“ their flock/herd that the problem exists in other and different ones then within its own flock/herd. By the way, all three sides speak the same language and say that they speak different languages. Why is that? Because the known linguists confirm that we can say that if the differences 
between languages are less than $40 \%$, people speak the same languages and here the differences are less than $15 \%$. For example, Bosniaks, Serbs and Croats do not need interpreter when talking to each other. Also, to quote famous German philosopher Fichte: "Nation equal language". So, they need to separate languages to be able to call themselves with different national names. In the same time, being no-catarsic shows that all three sides call their war - criminal heroes, still. Of course, International Tribunal in the legitimately established by UN has prosecuted that majority of the War Crimes have been committed by the Serbs, then by the Croats and then by the Bosniaks. Although, who killed even one innocent person during the war is a war criminal and not to talk about even Genocide such has happened in Srebrenica in 1995, Bosnian city of Eastern Bosnia and Herzegovina, when more than 8000 Bosniaks have been killed within of couple days by the side of Serbian forces. Journalists on all three sides (with just few, but brave examples on all three sides) serve the fascistic chauvinists (about which I already wrote in Eurasia Review online journal from the USA back in January 2020), populistic leaders of Bosniaks, Serbs and Croats within Bosnia and Herzegovina.

That said (There are legal frameworks in $\mathrm{BiH}$ that provide an undisturbed working atmosphere for journalists, and that is largely a good basis for respect for media freedom, but these do not apply in practice.), there is no adequate control of the application of these laws. The best way to properly control these laws would be the establishment of an independent parliamentary commission that would monitor the implementation of these laws every six months.

In addition to violent behavior towards the media, journalists are denied access to information, although we have, as I said earlier, the Laws on Freedom of Access to Information at all levels of Dayton (back in 1995) made in Bosnia and Herzegovina. Many of the businesses of the governing structures are hidden from the eyes of the public and completely unavailable to journalists, which shows a high degree of corruption in Bosnia and Herzegovina.

\section{THE LAWS AND HOW TO AVOID IT?}

The Law on Freedom of Access to Information stipulates that the deadline 
for the provision of information is 15 days, and misdemeanor sanctions are prescribed if the institution or other legal entity does not provide the information within that deadline, But there have been no effects of that provision so far - no one has been sanctioned due to denial of information to journalists up to date.

Journalists are today the target of many forces, from political to economic power potentates, but the truth is that media owners are now employing a staff who meets "house rules" and if he / she is not necessarily a good journalist.

Responsible journalism and media freedom can be protected. However, the job and work of journalists in $\mathrm{BiH}$ is heavily burdened by low wages and pressures from commercial advertisers, and because of these poor working conditions, journalists go down to lethargy and live in fear of their own existence.

The freedom of media journalists must defend with responsible journalism with high professional ethical standards. But, with a unanimous appearance. None of the journalists can do anything alone, but together they can do a lot. Journalists are often faced with various types of pressures and the duty of all journalists is to be with their colleagues and support them when needed. Journalism can be rescued by raising professional standards, and education outside of standard institutions is essential; scholarship programs such as BIRN and Reuters, Media Center workshops, and independent learning, as well as studying at universities that have no influence on this or that policy (whether it is social, economic, and / or political).

Responsible journalism starts with each of the individual journalists because the first - journalist is responsible to himself/herself, to the people around him, and then to all who may read what he/she writes and then to the profession itself.

There is lacking, first and foremost, of collegiality in the territory of Bosnia and Herzegovina, no matter about which kind of media we are talking about. For example, politicians have a meeting and allow journalists to 
wait for 5-6 hours in the winter cold, refuse to appear at a scheduled time. Why do not all journalists simply agree to leave the site and not report on the meeting? Yes, someone will probably stay and break the deal, but believe me, the politicians will do the same when such things happen on several occasions. There needs to be in the media, not a collegial grouping of just one or two, but an understanding that all must be involved.

For many, it is funny when, for example, Milorad Dodik "Serbian member of Bosnian presidency" jokes or offends one of their colleagues or they are silent about it. Journalists are still squatting for hours in all possible weather conditions waiting for the unpardonable end of a meeting, lunch or some other political event. It's as if we are cleaning the garbage in a stranger yards, and yet we do not see the trash in our own area of the media. How many journalists are still working in the black economy - working full-time, often more than ten hours a day, earns just a small amount of money? Media bosses have been employing journalists for many years on fake contracts, giving them a miserable salary. At least a third of them have not had internships and they are not paid for health and other benefits.

Of course, auto-censorship exists in the worst possible form. A large number of journalists are waiting for a job, so this means that there are the same number of people who think twice before editing something within the line of words. Journalists fail to convey to their colleagues how editors put pressure on them because they (editors) have been called from the "Central". Surreal reality is at work, and the freedom of journalistic speech has also been lost.

\section{CONCLUSION: BECOMING AND BEING ETHICAL}

We can conclude that there are numerous reasons for disturbing the dignity of the journalist profession, and for some, they are solely responsible - the journalists - and for others, there is a government that is accustomed to keeping the media "curbed".

Unfortunately, some practices that violate media rights have become permanent and are not likely to change until there is fundamental change in society as a whole (who mentioned Media Literacy?). 
However, even journalists are just humans. They too are people who, like other citizens of Bosnia and Herzegovina, suffer from extreme poverty and existential fear. Because of this they often work under rules and conditions that are counter to a positive media and are silent about what bothers them.

To avoid all of the above, and to create the prerequisites for the creation of professional ethical standards aimed at the creation of a healthy society, it is necessary to respect and implement five basic criteria that are the core part of every ethical system, including those belonging to professional journalists:

1. First of all, the ethical system must have common values relating to honesty, democracy, truth, objectivity, honesty and privacy. This is because before we can come to an ethical judgment, society must reach an agreement about standards of moral behavior.

2. The second criterion is that these standards must be established and based on reason and experience and they should harmonize the rights and interests of people with their obligations to other people.

3. Third, the ethical system must seek for justice. There must not be double standards of behavior unless there are compelling and morally viable grounds for discrimination.

4. The ethical system should be, as the fourth criterion, based on the freedom of choice and an ethics system that includes responsibility, to encourage honest behavior. If that is not done, then we get moral anarchy.

5. Finally, my firm stance is that I always use my own sentence in work and behavior: "However many rights I win, I must win the same amount of the responsibility."

And of course, how can we still better shape and not allow the continuation of the maintenance of moral anarchy? Should we focus on the Law or Ethics? The question of quality is unavoidable. 
Media Literacy: The Real, Interactive Way And Being Ethical Within Post Conflict Non-Catharsis Society In Bosnia And Herzegovina

What is important is that if a particular profession wants to call itself professional, it has to do its job on an ethical basis with what is most important - those who accomplish it must be responsible for their work and acts.

So, until we meet this: "Rights equal responsibility; Responsibility equal empathy and Empathy equal Equality" we will not be able to talk about any of mentioned goals above. In Bosnia and Herzegovina, but also wider. 


\section{REFERENCES}

[1] Book "Visible Man and Spirit of Film", 1924-1930, Publisher Berghahn, USA, in Association with Screen, September 2011 - http://www. berghahnbooks.com/title/BalazsEarly 7 Cannons of journalism: https:// macyburford.wordpress.com/2013/10/09/the-7-cannons-of-journalism/ (last approached on 20.7.2020)

[2] Committee to Protect Journalists (2018): https://cpj.org/data/ imprisoned $/ 2018 /$ ? status $=$ Imprisoned \&start_year $=2018 \&$ end year $=2018 \&$ group_by=location (last approached on 21.7.2019)

[3] Declaration on Media Education (Grunwald, Federal Republic of Germany), 1977: http://www.unesco.org/education/pdf/MEDIA_E.PDF (approached on 21.07.2020)

[4] Example of anti-journalism - Newspaper „Dnevni Avaz“, Sarajevo, BiH: http://www.media.ba/bs/mediametar/novina-protiv-novinara

[5] European Convention for the Protection of Human Rights and Fundamental Freedoms (Rome, Italy,1950): https://rm.coe.int/1680063765 (last approached on 22.7.2020) 